\title{
Crustal thickening in the Neoarchean: geochemical records by potassic granitoids from the Taihua Complex in the North China Craton and worldwide
}

\author{
ZHEN-XIN LI, SHAO-BING ZHANG AND YONG-FEI \\ ZHENG
}

CAS Key Laboratory of Crust-Mantle Materials and Environments, School of Earth and Space Sciences, University of Science and Technology of China

Presenting Author: geolzx@mail.ustc.edu.cn

The Earth system shows many fundamental changes during the Neoarchean. In this period, the diversification of felsic rocks initiated, and crustal composition changed from sodic TTGsdominated to potassic granites-dominated. However, the mechanism that drove this change remains uncertain.

Here we report a geochemical study of Neoarchean TTG gneisses and potassic granites from the Taihua Complex in the North China Craton. The ca. 2.65 Ga TTG rocks are characterized by low $\mathrm{K}_{2} \mathrm{O} / \mathrm{Na}_{2} \mathrm{O}$ ratios of $<0.6$, high $\mathrm{Sr} / \mathrm{Y}$ and $(\mathrm{La} / \mathrm{Yb})_{\mathrm{N}}$ ratios, positive $\mathrm{Eu}$ anomalies, positive zircon $\varepsilon_{\mathrm{Hf}}(\mathrm{t})$ values of 0.9 to 5.2 , zircon $\delta^{18} \mathrm{O}$ values of $6.3-6.5 \%$, which are attributed to partial melting of the basaltic oceanic crust at depths of $>35 \mathrm{~km}$. The ca. $2.65 \mathrm{Ga}$ potassic granites have high $\mathrm{K}_{2} \mathrm{O} / \mathrm{Na}_{2} \mathrm{O}$ ratios of $>0.6$, low $\mathrm{Sr} / \mathrm{Y}$ and $(\mathrm{La} / \mathrm{Yb})_{\mathrm{N}}$ ratios, negative $\mathrm{Eu}$ anomalies, zircon $\varepsilon_{\mathrm{Hf}}(\mathrm{t})$ values of -0.4 to 8.0 , zircon $\delta^{18} \mathrm{O}$ values of $7.0-8.4 \%$, which are ascribed to partial melting of the mafic continental crust at shallower depths of $<35 \mathrm{~km}$. Compared to the ca. $2.65 \mathrm{Ga}$ potassic granites, the ca.2.55-2.50 Ga potassic TTGs show higher $(\mathrm{La} / \mathrm{Yb})_{\mathrm{N}}$ and $\mathrm{Sr} / \mathrm{Y}$ ratios, suggesting their derivation from partial melting of the thickened continental crust. The increases of both $\mathrm{Sr} / \mathrm{Y}$ and $(\mathrm{La} / \mathrm{Yb})_{\mathrm{N}}$ ratios from the ca. 2.65 Ga potassic granites to the ca. 2.55-2.50 Ga potassic TTGs reflect a process of the crustal thickening.

Using a filtered global geochemical database of potassic granites within the age range of 4.0-2.4 Ga, we find that the potassic granites have higher $\mathrm{K}_{2} \mathrm{O}$ but similar or lower $\mathrm{Na}_{2} \mathrm{O}$ contents compared to the TTGs. This argues against the formation of potassic granites through partial melting or fractionation of TTGs. Instead, the mafic continental crust is suggested as a possible source because of high $\mathrm{K}_{2} \mathrm{O}$ contents compared to primary oceanic crust. The ages of Archean potassic granites show peaks at 2.8-2.6 Ga. The $\mathrm{Sr} / \mathrm{Y}$ and $(\mathrm{La} / \mathrm{Yb})_{\mathrm{N}}$ ratios of global potassic granites begin to increase in the Neoarchean, suggesting the continental crust was gradually thickened in this stage. 